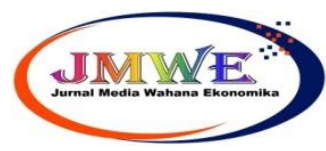

IS.SN 16.9.3-4n.91 F-IS.SN 2627-184.

https://jurnal.univpgri-palembang.ac.id/index.php/Ekonomika/index

\title{
Analisis Rasio Profitabilitas dan Rasio Pertumbuhan (Growth) Pada Perusahaan Sub Sektor Pulp And Paper yang terdaftar di Bursa Efek Indonesia
}

\author{
Hendry Saladin ${ }^{1}$, Oktariansyah ${ }^{2}$ \\ ${ }^{1}$ Akuntansi, F. Ekonomi dan Bisnis, Universitas PGRI Palembang, hendrysaladin62@gmail.com \\ ${ }^{2}$ Akuntansi, F. Ekonomi dan Bisnis Universitas PGRI Palembang, rianbro82@univpgri-palembang.ac.id
}

\begin{abstract}
ABSTRAK
Penelitian ini bertujuan untuk mengetahui kinerja keuangan pada Rasio Profitabilitas dan Rasio Pertumbuhan pada Perusahaan Sub Sektor Pulp dan Kertas yang terdaftar di Bursa Efek Indonesia (BEI) dengan menganalisis Laporan Keuangan perusahaan. Data yang diamati merupakan laporan posisi keuangan (neraca) dan laporan laba rugi pada tahun 2017 sampai 2019. Analisis data dan pembahasan dengan menggunakan metode kuantitatif,yaitu menerangkan dengan cara menghitung rasio profitabilitas dengan menggunakan rasio Return On Asset (ROA), Return On Equity (ROE) dan rasio pertumbuhan Earning Per Share (EPS). Hasil pembahasan dapat diketahui bahwa rasio profitabilitas pada PT. Alkindo Naratama.Tbk diukur dengan rasio profitabilitas mengalami penurunan. Dihitung dengan rasio ROA tahun 2017 sebesar 5,82\%, 2018 sebesar 5,47\%, dan tahun 2019 naik sebesar 6,08\%. ROE tahun 2017 sebesar $12.66 \%, 2018$ sebesar 10,75\%, 2019 sebesar 10,55\%. Dan rasio pertumbuhan dengan menggunakan Rasio EPS pada tahun 2017 sebesar Rp.23,95, 2018 sebesar Rp.28,72 , 2019 sebesar Rp.29,35. Pada PT. Toba Pulp Lestari.Tbk diukur dengan rasio profitabilitas secara keseluruhan dengan rasio ROA tahun 2017 sebesar $7,30 \%, 2018$ sebesar $0,11 \%$, 2019 sebesar $-4,05 \%$. ROE tahun 2017 sebesar 15,13\%, 2018 sebesar 0,27\%, 2019 sebesar12,94\%. dan rasio pertumbuhan menggunakan Rasio EPS pada tahun 2017 sebesar Rp.240,36, 2018 sebesar Rp.4,86, 2019 sebesar Rp.-14,12. PT. Tjiwi Kimia Tbk. Secara keseluruhan dikategorikan mengalami peningkatan pada setiap tahunnya. Di hitung dengan menggunakan rumus ROA tahun 20171,06 \%, 2018 sebesar 8,45\%, 2019 sebesar 5,40\% dikategorikan baik. ROE tahun 2017 2,78\%, 2018 19,99\%, 2019 sebesar12,01\%, dikategorikan baik. Dan rasio pertumbuhan dengan menggunakan Rasio EPS pada tahun 2017 Rp.118.85 , 2018 sebesar Rp.1,188,73, 2019 sebesar Rp.53,48.
\end{abstract}

Kata Kunci: ROA, ROE, EPS

\begin{abstract}
This study aims to determine the financial performance of profitability ratios and growth ratios in pulp and paper sub-sector companies listed on the Indonesia Stock Exchange (BEI) by analyzing the company's financial statements. The data observed is a statement of financial position (balance sheet) and income statement from 2017 to 2019. Data analysis and discussion using quantitative methods, namely explaining by calculating the profitability ratio using the ratio of Return On Asset (ROA), Return On Equity (ROE) and the growth ratio of Earning Per Share (EPS). The results of the discussion can be seen that the profitability ratio at PT. Alkindo Naratama.Tbk is measured by the decreasing profitability ratio. It is calculated by the ROA ratio in 2017 of $5.82 \%, 2018$ of $5.47 \%$, and in 2019 it increased by $6.08 \%$. ROE in 2017 was $12.66 \%, 2018$ was $10.75 \%, 2019$ was $10.55 \%$. And the growth ratio using the EPS ratio in 2017 is IDR 23.95, 2018 IDR 28.72, 2019 IDR 29.35. At PT. Toba Pulp Lestari.Tbk is measured by the overall profitability ratio with an ROA ratio in 2017 of $7.30 \%, 2018$ of $0.11 \%, 2019$ of $-4.05 \%$. ROE in 2017 is $15.13 \%, 2018$ is $0.27 \%, 2019$ is $-12.94 \%$. and the growth ratio using the EPS ratio in 2017 was Rp. 240.36, 2018 amounting to Rp.4.86, 2019 amounting to Rp.14.12. PT. Tjiwi Kimia Tbk. Overall categorized as experiencing an increase every year. Calculated using the ROA formula for $20171.06 \%, 2018$ at $8.45 \%, 2019$ at $5.40 \%$ categorized as good. ROE in 2017 was $2.78 \%, 201819.99 \%, 2019$ was $12.01 \%$, categorized as good. And the growth ratio using the EPS ratio in 2017 is Rp. 118.85, 2018 is Rp. 1,188.73, 2019 is Rp. 53.48.
\end{abstract}

Keywords: ROA, ROE, EPS

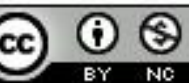




\section{A. PENDAhULUAN}

Kertas merupakan kebutuhan manusia sehari-hari, salah satupenggunaannya seperti pada surat kabar, majalah, kemasan, kertas cetak, dan lain-lain. Data Kementerian Perindustrian menunjukkan kebutuhan kertas diera global saat ini berkisar 394 juta ton. Jumlah ini diprediksi tumbuh $24,4 \%$ menjadi 490 juta ton pada 2020. Konsumsi kertas di dunia diramalkan tumbuhmerata 2,1\% per tahun, sedangkan pasar negaranegara berkembang naik 4,1\%per tahun dan negara maju $0,5 \%$ (www.kemenperin.go.id).

Sektor pulp and paper merupakan industri perusahaan yang bergerakdibidang produksi kertas dan bubur kertas, terdapat 8 perusahaan sektor pulpand paper yang terdaftar di Bursa Efek Indonesia. Meningkatnya kebutuhan kertas akan menyebabkan meningkatnya jumlah penjualan pada perusahaan yang bergerak memproduksi kertas dan bubur kertas yaitu sektor pulp and paper.

Kondisi tersebut akan mempengaruhi kinerja keuangan perusahaan pada sektor pulp and paper. Penilaian untuk mengetahui kinerja keuangan perusahaan biasanya dengan cara menganalisis laporan keuangan suatu perusahaan. Dalam menganalisis kinerja keuangan perusahaan pada umumnyamenggunakan analisis rasio, salah satu indikator dalam analisis rasio adalah Laporan Keuangan Perusahaan.

Faktor yang mempengaruhi return saham adalah kinerja keuangan perusahaan itu sendiri. Oleh karena itu, terdapat hubungan antara kondisi perekonomian dengan kinerja keuagan perusahaan.

Kinerja keuangan suatu perusahaan merupakan prospek pertumbuhan potensi perkembangan yang baik bagi perusahaan. Sedangkan laporan keuangan melaporkan posisi perusahaan pada suatu titik waktu dan kegiatan operasinya selama beberapa periode lalu. Namun, nilai riilnya ada pada kenyataan bahwalaporan tersebut dapat digunakan untuk membantu meramalkan laba dan dividen masa depan. Dari sudut pandang investor, peramalan masa depan adalah inti dari analisis keuangan yang sebenarnya.Laporan keuangan untuk mengevaluasi efektifitas dan efisiensi manajemen perusahaan dalam mengelola seluruh aktiva perusahaan atau mengukurkinerja perusahaan dengan rasio laba bersih terhadap total asset, karena semakinbesar Return On Asset (ROA),berarti semakin efisien penggunaan aktiva perusahaan atau dengan kata lain dengan jumlah aktiva yang sama bisa dihasilkan laba yang lebih besar, dan sebaliknya semakin kecil Return On Asset $(R O A)$,semakin tidak efisien penggunaan aktiva perusahaan atau dengan kata lain dengan jumlah aktiva yang sama tidak bisa menghasilkan laba yang lebih besar.

Tingkat inflasi juga akan mempengaruhi kinerja perusahaan. Tingginya tingkat inflasi dapat membuat pendapatan rill masyarakat (konsumen) menurun dan akan mengurangi daya beli. Sebaliknya, apabila tingkat inflasi rendah, maka daya beli konsumen akan meningkat. Daya beli konsumen terhadap barang dan jasa akan sangat mempengaruhi profitabilitas sebuah perusahaan. Misalnya, apabila daya beli konsumen terhadap produk makanan dan minuman diprediksi meningkat, perusahaan akan menjual lebih banyak produk makanan dan minuman yang secara otomatis akan meningkatkan laba. 
Investor mempunyai kepentingan terhadap informasi tentang Return onEquity (ROE) dan Return on Assets (ROA) dalam melakukan prediksi pembagian deviden yang akan diterima. ROA dan ROE menggambarkan kemampuan perusahaan dalam menghasilkan keuntungan bersih setelah pajak dengan menggunakan modal sendiri dan seluruh aktiva/aset yang dimiliki.Semakin tinggi ROA dan ROE maka semakin tinggi tingkat keuntungan pemilik perusahaan. Tingkat keuntungan pemilik perusahaan yang tinggi akan meningkatkan EPS perusahaan dan dapat meningkatkan kemampuan perusahaan dalam membayar dividen.

Harga saham setiap waktu dapat berubah-ubah tergantung pada besarnya penawaran dan permintaan investor akan saham tersebut. Faktorfaktor yang dapat memengaruhi naik turunnya harga saham suatu perusahaan adalah faktor internal dan faktor eksternal perusahaan tersebut. Penelitian ini menggunakan faktor internal perusahaan yang tercermin dalam laporan keuangan perusahaan. Faktor internal perusahaan yang digunakan berupa rasio-rasio keuangan seperti rasio profitabilitas yang diproksikan dengan Return on Asset (ROA), Return on Equity (ROE) dan rasio pertumbuhan yang diproksikan dengan Earning Per Share (EPS).

EPS adalah rasio yang digunakan untuk mengukur seberapa besar pengakuan pasar akan suatu perusahaan dengan membandingkan antara laba bersih dengan jumlah lembar saham yang beredar di pasaran. EPS yang meningkat menandakan bahwa perusahaan berhasil meningkatkan kemakmuran investor dengan berupa pembagian dividen. Hal ini dapat meningkatkan permintaan investor akan saham yang nantinya akan menyebabkan semakin meningkat pula harga saham perusahaan tersebut. (Tandelilin, Eduardus, 2010: 365)

Ketatnya persaingan antar perusahan pulp dan kertas dalam negeri berikut isuglobal mengenai sosial dan lingkungan yang semakin menjadi fokus industry dinilai cukup dahsyat mempengaruhi kinerja industri tersebut. Meskipun pertumbuhan ekonomi mendorong pasar domestik memberikan peluang usaha, halini dilemahkan dengan keterkaitan industri pulp dan kertas dengan isu kelestarian lingkungan yang kerap diembuskan kritik dan tudingan negatif yang kurang menggembirakan. Namun terdapat pula permasalahan lain, yaitu perusahaan dalam industri ini memiliki produktivitas aset yang rendah sehingga diduga tidak berpotensi menciptakan nilai tambah bagi perusahaan.

\section{B. KAJIAN TEORI}

a) Pengertian Laporan Kuangan

Menurut IAI (2013:120) laporan keungan adalah laporan yang menggambarkan posisi keuangan, kinerja keuangan dan arus kas entitas.

Menurut Hery (2016:2) laporan keuangan (financial statement) merupakan produk akhir dari serangkaian proses pencatatan dan pengikhtisaran data transaksi bisnis.

Menurut Kasmir (2010:9) laporan keuangan adalah laporan yang dibuat berkaitan dengan laporan keuangan yang disajikan. Laporan ini memberikan informasi tentang penjelasan yang dianggap perlu atas laporan keuangan yang ada sehingga menjadi jalas sebab penyebabnya.
b) Jenis-jenis Laporan Keuangan
Kasmir
(2017:67)
mengemukakan bahwa dalam 
praktiknya, secara umum ada lima macam jenis laporan keuangan yang biasa disusun yaitu:

a. Neraca

Neraca merupakan laporan yang menunjukkan jumlah aktiva (harta), kewajiban (utang), dan modal perusahaan (ekuitas) perusahaan pada saat tertentu.

b. Laporan Laba Rugi

Laporan laba rugi Merupakan laporan keuangan yang menggambarkan hasil usaha perusahaan dalam suatu periode tertentu

c. Laporan Perubahan Modal

Laporan perubahan modal merupakan laporan yang menggambarkan jumlah modal yang di miliki perusahaan saat ini. Kemudian laporan ini juga menunjukkan perubahan modal serta sebab-sebab perubahannya modal.

d. Laporan Catatan Atas Laporan Keuangan

Laporan catatan atas laporan keuangan merupakan laporan yang dibuat berkaitan dengan laporan keuangan yang disajikan. Laporan ini memberikan informsi tentang penjelasan yang dianggap perlu atas laporan keuangan yang ada sehingga menjadi sebab penyebabnya.

e. Laporan Arus Kas

Laporan arus kas merupaka laporan yang menunjukan arus kas masuk dan arus kas keluar di perusahaan.

\section{c) Pengertian Pasar Modal}

Pasar modal (capital market) merupakan pasar untuk berbagai instrumen keuangan jangka panjang yang bisa diperjualbelikan, baik suratutang (obligasi), ekuiti (saham), reksa dana, instrumen derivatif maupun instrumen lainnya. Pasar modal merupakan sarana pendanaan bagi perusahaan maupun institusi lain (misalnya pemerintah), dan sebagai sarana bagi kegiatan berinvestasi. Dengan demikian pasar modal memfasilitasi berbagai sarana dan prasarana kegiatan jual beli dan kegiatan terkait lainnya.(Ridwan, 2012:429)

Pasar modal juga sama seperti pasar pada umumnya, yaitu tempat bertemunya antara penjual dan pembeli. Menurut Scott, pasar modal adalah pasar untuk jangka panjang di mana saham biasa, saham preferen dan obligasi diperdagangkan. Sementara itu, menurut Christoper Pass dan Bryan Lower, pasar modal adalah suatu tempat melakukan pembelian dan penjualan obligasi dan saham perusahaan serta obligasi pemerintah. Dengan demikian, pengertian pasar modal adalah transaksi yang dilakukan melalui mekanisme Over The Counter. (Veitzal Rivai, dkk, 2012 : 927)

Menururt Tendelilin (2010:26) pasar modal adalah pertemuan antara pihak yang memiliki kelebihan dana dengan pihak yang membutuhkan dana dengan cara memperjual belikan sekuritas. Dengan demikian, pasar modal juga dapat diartikan sebagai pasar untuk memperjual belikan sekurutas yang umumnya memiliki umur lebih dari satu tahun, seperti saham dan obligasi.

Undang-undang Pasar Modal No. 8 Tahun 1995 tentang Pasar Modal di Indonesia mendefinisikan pasar modal sebagai "kegiatan yang bersangkutan dengan Penawaran Umum dan Perdagangan Efek, perusahaan publik yang berkaitan dengan efek yang diterbitkannya, serta lembaga dan profesi yang berkaitan dengan efek. Efek merupakan istilah buku yang digunakan undang - undang untuk 
menyatakan surat berharga atau sekuritas.

\section{d) Analisis Rasio Keuangan}

Menurut Hery (2016:20) Analisis rasio keuangan adalah analisis yang dilakukan dengan menghubungkan berbagai perkiraan yang ada pada laporan keuangan dalam bentuk rasio keuangan. Analisis rasio keuangan ini dapat mengungkapkan hubungan penting antara perkiraan laporan keuangan dan dapat digunakan untuk mengevaluasi kondisi keuangan dan kinerja perusahaan.

Menurut Kasmir (2010:92) Rasio keuangan merupakan kegiatan menbandingkan angka-angka yang ada dalam laporan keuangan dengan cara membagi satu angka dengan angka lainnya. Perbandingan dapat dilakukan antara satu komponen dengan komponen dalam satu laporan keuangan atau antar komponen yang ada diantara laporan keuangan. Kemudian angka yang diperbandingkan dapat berupa angkaangka dalam satu periode maupun beberapa periode.

\begin{tabular}{|c|c|}
\hline Menurut & Munawir \\
\hline $\begin{array}{l}\text { Analisis } \\
\text { nerupakan }\end{array}$ & $\begin{array}{l}\text { Laporan } \\
\text { rasio }\end{array}$ \\
\hline
\end{tabular}
menggambarkan suatu hubungan atau perimbangan antara suatu jumlah tertentu dengan jumlah yang lain, dan menggunakan alat analisa berupa rasio ini akan dapat menjelaskan atau memberikan gambaran kepada penganalisa tentang baik atau buruknya keadaan posisi keuangan suatu perusahaan terutama apabila angka rasio tersebut dibandingkan dengan angka rasio pembanding yang digunakan sebagai standar.

Dengan demikian manfaat suatu analisis rasio sepenuhnya bergantung pada kemampuan dan kecerdasan analisis dalam menginterprestasikan data yang bersangkutan.

\section{e) Jenis-Jenis Rasio Keuangan}

Menurut Kasmir (2010:110) secara umum, analisis rasio keuangan dapat digolongkan sebagai berikut:

a. Rasio Likuiditas

Rasio likuiditas (Liquidity ratio) merupakan rasio yang menggambarkan kemampuan perusahaan memenuhi kewajiban (utang) jangka pendek. Artinya apabila perusahaan di tagih, maka akan mampu untuk memenuhi utang (membayar) terutama utang yang sudah jatuh tempo.

b. Rasio Solvabilitas (Leverage)

Rasio solvabilitas merupakan tasio yang digunakan untuk mengukur sejauh mana aktiva perusahaan dibiayai dengan utang. Dalam arti luas dikatakan bahwa rasio solvabilitas digunakan untuk mengukur kemampuan perusahaan untuk membayar seluruh kewajibannya baik jangka pendek maupun jangka panjang apabila perusahaan dibubarkan (dilikuidasi).

c. Rasio Aktivitas

Rasio aktivitas (activity ratio), merupakan rasio yang digunakan untuk mengukur efektifitas perusahaan dalam menggunakan aktiva yang dimilikinya. Rasio aktivitas juga juga di gunakan untuk menilai kemampuan perusahaan dalam melaksanakan aktivitas sehari-hari.

d. Rasio Profitabilitas

Rasio profitabilitas merupakan rasio untuk menilai kemampuan perusahaan dalam mencari keuntungan. Rasio ini juga memberikan ukuran tingkat efektivitas manajemen suatu perusahaan.

e. Rasio pertumbuhan

Rasio pertumbuhan (Growth ratio), merupakan rasio yang menggambarkan kemampuan 
perusahaan mempertahankan posisi ekonominya ditengah pertumbuhan perekonomian dan sektor usahanya. Dalam rasio yang di analisis adalah pertumbuhan penjualan, pertumbuhan laba bersih, pertumbuhan pendapatan persaham dan pertumbuhan deviden persaham.

f. Rasio Penilaian

Rasio penilaiaan (Valuation Ratio), yaitu rasio yang memberikan ukuran kemampuan manajemen menciptakan nilai pasar usahannya diatas biaya investasi.

Harga Saham adalah harga suatu saham pada pasar yang sedang berlangsung di Bursa Efek. Harga Saham dapat dipengaruhi oleh situasi pasar antara lain harga saham dipasar perdana ditentukan oleh penjamin emisi dan perusahaan yang akango public (emiten), berdasarkan analisis fundamental perusahaan. Peranan penjamin emisi pada pasar perdana selain menentukan harga saham, juga melaksanakan penjualan saham kepada masyarakat sebagai calon pemodal. Harga saham merupakan harga jual beli yang sedang berlaku di pasar efek yang ditentukan oleh kekuatan pasar dalam arti tergantungan pada kekuatan permintaan (penawaran) dan penawaran (permintaan jual).

Harga pasar saham juga menunjukkan nilai dari perusahaan itu sendiri. Semakin tinggi nilai dari harga pasar saham suatu perusahaan, maka investor akan tertarik untuk menjual sahamnya. Bursa saham merupakan salah satu indikator perekonomian suatu negara maka diperlukan suatu pertimbangan tentang transaksi yang terjadi dalam bursa sepanjang periode tertentu. Perhitungan ini akan digunakan sebagai tolak ukur kondisi perekonomian suatu negara. Untuk di Negara di Indonesia perhitungan tersebut adalah perhitungan Indeks Harga Saham Gabungan (IHSG).

Menurut Undang-undang No. 8 Tahun 1995 Harga Pasar Saham adalah harga suatu saham yang sedang berlangsung dalam suatu Pasar Modal.Jika bursa tutup maka harga saham pasarnya adalah terbesar pada saat penutupan (closing price).Harga pasar saham adalah harga yang terbentuk di pasar jual beli saham.

\section{g) Analisis Fundamental}

Analisis fundamental adalah metode analisis yang didasarkan pada fundamental ekonomi suatu perusahaan. Teknik ini menitikberatkan pada rasio finansial dan kejadian-kejadian yang secara langsung maupun tidak langsung memengaruhi kinerja keuangan perusahaan. Analisis fundamental berkaitan dengan penilaian kinerja perusahaan, tentang efektifitas dan efisiensi perusahaan dalam mencapai sasarannya.(Lukman, 2011:43)

Analisis fundamental merupakan pendekatan analisis harga saham yang menitik beratkan pada kinerja perusahaan yang mengeluarkan saham dan analisis ekonomi yang akan mempengaruhi masa depan perusahaan. Kinerja perusahaan dapat dilihat dari perkembangan perusahaan, neraca perusahaan dan laporan laba ruginya, proyeksi usaha dan rencana perluasan dan kerjasama. Pada umumnya apabila kinerja perusahaan mengalami perkembangan yang baik, maka harga saham akan meningkat.(Sutrisno, 2012:309)

\section{h) Faktor-faktor yang Memengaruhi Harga Saham \\ Ada beberapa kondisi dan situasi yang menentukan suatu saham itu}


mengalami fluktuasi, yaitu: (Irham Fahmi, 2012 : 87)

1) Kondisi mikro dan makro ekonomi;

2) Kebijakan perusahaan dalam memutuskan untuk ekspansi (perluasan usaha), seperti membuka kantor cabang, kantor cabang pembantu baik yang dibuka di domestik maupun luar negeri.

3) Pergantian direksi secara tibatiba

4) Adanya direksi atau pihak komisaris perusahaan yang terlibat tindak pidana dan kasusnya sudah masuk ke pengadilan

5) Kinerja perusahaan yang terus mengalami penurunan dalam setiap waktunya

6) Resiko sistematis, yaitu suatu bentuk risiko yang terjadi secara menyeluruh dan telah ikut menyebabkan perusahaan ikut terlibat

7) Efek dari psikologi pasar yang ternyata mampu menekan kondisi teknikal jual beli saham.

Harga saham dapat berubah baik karena adanya informasi baru yang rasional maupun tanpa informasi baru, sehingga perubahan harga tersebut dianggap tidak rasional melainkan emosional.Pergerakan harga saham setiap detik selalu dipelajari oleh banyak day trader yang berdagang dengan cara beli pagi hari dan jual sore hari, atau jual pagi hari dan beli sore hari.

\section{METODE PENELITIAN}

Menurut Anwar Sanusi (2012:50) variabel penelitian adalah suatu fenomena yang diabstraksikan menjadi konsep atau konstruk yang jika diberi nilai.
Menurut Sugiyono (2013:58) variabel penelitian adalah segala sesuatu yang berbentuk apa saja yang di tetapkan oleh peneliti untuk dipelajari, sehingga diperoleh informasi tentang hal tersebut, kemudian ditarik kesimpulannya.

\section{1) Populasi dan Sampel}

a) Populasi

Menurut Sedarmayanti dan Hidayat (2011:121), populasi adalah himpunan keseluruhan karakteristik dan objek peneliti.

MenurutSugiyono

(2013:80)

Populasi adalah wilayah generasi terdiri atas objek atau subjek yang mempunyai kualitas dan karakteristik tertentu. Ditetapkan oleh peneliti untuk dipelajari dan ditarik kesimpulan.

Populasi dalam penelitian ini adalah 3 perusahaan Pulp And Paper yang terdaftar di Bursa Efek Indonesia (BEI):

Tabel Perusahaan Pulp And Paper

\begin{tabular}{|c|l|}
\hline No & \multicolumn{1}{|c|}{ Nama Perusahaan } \\
\hline 1 & Alkindo NaratamaTbk. \\
\hline 2 & Toba Pulp Lestari Tbk. \\
\hline 3 & $\begin{array}{l}\text { Pabrik Kertas Tjiwi Kimia } \\
\text { Tbk. }\end{array}$ \\
\hline
\end{tabular}

Sumber : Bursa Efek Indonesia (BEI)

b) Sampel

Menurut Sedarmayanti dan Hidayat (2011:123), sampel adalah kelompok kecil yang diamati dan merupakan bagian dari populasi sehingga sifat dan karakteristik populasi juga dimiliki oleh sampel.

Menurut Sugiyono (2013:81) sampel adalah Sebagian dari jumlah dan karakteristik yang dimiliki oleh populasi tersebut. 
Sampel dalam penelitian ini adalah data keuangan atau laporan keuangan, Neraca dan Laporan Laba Rugi dari tiga perusahaan Pulp And Paper, di Bursa Efek Indonesia. Data yang diambil yaitu mulai dari tahun 2017- 2019.

\section{2) Sumber Data}

Terdapat dua sumber data yaitu data primer dan sekunder.

1) Data Primer

Menurut Uma Sekaran (2011:76) data primer adalah data yang mengacu pada informasi diperoleh dari tangan pertama oleh peneliti yang berkaitan dengan variabel minat untuk tujuan spesifikasi studi. Sumber data primer adalah responden indifidu, kelompok fokus, internet juga dapat menjadi sumber data primer jika koesioner disebarkan melalui internet. Menurut Sugiyono (2013:223) sumber primer adalah sumber data yang langsung memberikan data kepada pengumpulan data.

2) Data Sekunder

Menurut Uma Sekaran (2011:76) data sekunder data yang mengacu pada informasi yang dikumpulkan dari sumber yang telah ada. Sumber data sekunder adalah catatan atau dokumentasi perusahaan, publikasi pemerintah, analisis industri oleh media, situs web, internet dan lain-lain. Menurut Sugiyono (2013:226) Data sekunder adalah sumber data yang tidak langsung memberikan data kepada pengumpul data, misalnya lewat orang lain atau lewat dokumen.

Penelitian ini menggunakan data sekunder karena data yang didapat berupa dokumen dan data dikumpulkan dengan cara melakukan dokumentasi yang di peroleh dari pojok Bursa Efek Indonesia Unika Musi Charitas Palembang.

\section{3) Teknik Pengumpulan Data}

Dalam memperoleh data-data yang akurat dan relevan sesuai dengan rumusan masalah pada penelitian ini, peneliti menggunakan penelitian studi pustaka dan dokumentasi. Uraian mengenai Teknik pengumpulan data yang dilakukan dalam penelitian ini antara lain sebagai berikut:

a. Tinjauan Kepustakaan
Teknik pengumpulan data ini bertujuan untuk mempelajari lebih dalam konsep dan teori yang berhubungan dengan penelitian sehingga mendapatkan landasan teori yang memadai untuk melakukan penelitian. Teknik ini dilakukan untuk menunjang kelengkapan data dengan menelaah literatur Pustaka seperti buku, skripsi, jurnal, dan sumber referensi lainnya yang berhubungan dengan analisis kinerja keuangan perusahaan.

b. Dokumentasi

Dokumentasi menurut Sugiyono (2013:204) merupakan catatan peristiwa yang sudah berlalu. Dokumen bisa berbentuk tulisan, gambar, atau karya-karya monumental.

\section{4) Teknik Analisa Data}

Dalam menganalisa data, penulis menggunakan teknik data secara kuantitatif yaitu:

a) Rasio Profitabilitas

Rasio ini mengukur kemampuan perusahaan menghasilkan keuntungan (profitabilitas) pada tingkat penjualan, aset, dan modal saham tertentu. Rasio ini terdiri dari Return on Asset dan Return on Equity. (Mamduh, 2012:79) 
Return on Asset (ROA)

Return on Asset (ROA) merupakan rasio keuangan yang digunakanuntuk menunjukan seberapa kontribusi asset dalam menciptakan laba bersih. Dengan kata lain rasio ini mengukur perusahaan menghasilkan laba berdasarkan pada tingkat asset tertentu. Sehingga semakin besar ROA menunjukan semakin efektif perusahaan dalam menggunakan total aktiva. Return on asset juga sering disebut return on investment.

ROA dihitung dengan menggunakan rumus sebagai berikut:

ROA

Tabel Skor Penilaian ROA

\begin{tabular}{|c|c|c|}
\hline Peringkat & Rasio & Keterangan \\
\hline 1 & $\mathrm{ROA}>1,5 \%$ & Sangat Baik \\
\hline 2 & $1,25 \%<\mathrm{ROA}<=1,5 \%$ & Baik \\
\hline 3 & $0,5 \%<\mathrm{ROA}<=1,25 \%$ & Cukup Baik \\
\hline 4 & $0 \%<\mathrm{ROE}<=0,5 \%$ & Kurang Baik \\
\hline 5 & $\mathrm{ROE}<=0 \%$ & Tidak Baik \\
\hline
\end{tabular}

Sumber : Keputusan Mentri BUMN Nomor: KEP-100/MBU/2002

Return on Equity (ROE)

Return on Equity (ROE) merupakan rasio untuk mengukur tingkat profitabilitas perusahaan, yaitu mengukur kemampuan perusahaan untuk menghasilkan laba. Rasio ini mengukur efisiensi perusahaan dalam menghasilkan laba dengan menggunakan equitas (modal sendiri) yang ada. Semakin tinggi nilai ROE makan semakin baik.(Franky, 2011:27) Bagi para pemegang saham semakin tinggi rasio ini maka akan semakin baik karena memberikan tingkat pengembalian yang lebih besar untuk pemegang saham. Rasio ini bisa dihitung dengan membagi laba bersih dengan jumlah equitas perusahaan. ROE dapat dihitung dengan rumus sebagai berikut: ROE $=\frac{\text { LABA BERSIH SETELAH PAJAK }}{\text { TOTAL EQUITAS } / \text { MODAL }}$ 
Tabel Skor Penilaian ROE

\begin{tabular}{|c|c|c|}
\hline Peringkat & Rasio & Keterangan \\
\hline 1 & $\mathrm{ROE}>15 \%$ & Sangat Baik \\
\hline 2 & $12,5 \%<\mathrm{ROE}<=15 \%$ & Baik \\
\hline 3 & $5 \%<\mathrm{ROE}<=12,5 \%$ & Cukup Baik \\
\hline 4 & $0 \%<\mathrm{ROE}<=5 \%$ & Kurang Baik \\
\hline 5 & $\mathrm{ROE}<=0 \%$ & Tidak Baik \\
\hline
\end{tabular}

Sumber: Keputusan Mentri BUMN Nomor: KEP-100/MBU/2002

b) Rasio Pertumbuhan

Rasio pertumbuhan (Growth ratio), merupakan rasio yang menggambarkan kemampuan perusahaan mempertahankan posisi ekonominya ditengah pertumbuhan perekonomian dan sektor usahanya. Rasio yang digunakan yaitu EARNING PER SHARE (EPS). (Kasmir, 2010:110)

Earning per Share (EPS)

Earning per Share (EPS) merupakan rasio untuk mengukur keberhasilan manajemen dalam mencapai keuntungan bagi pemegang saham. Semakin tinggi nilai EPS tentu saja menggembirakan pemegang saham karena semakin besar laba yang disediakan untuk pemegang saham. Rasio laba menunjukan dampak gabungan dari likuiditas serta manajemen aktiva dan kewajiban terhadap kemampuan perusahaan menghasilkan laba. Jadi, disimpulkan bahwa EPS merupakan suatu rasio yang menunjukkan jumlah laba yang di dapatkan dari setiap lembar saham yang ada. Berikut rumus dalam menghutung EPS (Kasmir, 2012 : 207):

$$
\text { EPS }=\frac{\text { LABA BERSIH SETELAH PAJAK }}{\text { JUMLAH SAHAM YANG BEREDAR }}
$$

\section{HASIL PENELITIAN DAN PEMBAHASAN}

1. Penyajian Data

Data yang digunakan untuk mengukur masing-masing variable penelitian, diperlukan indikator untuk menghitung variable penelitian adalah data laba bersih setelah pajak, total aktiva, total equitas, dan jumlah saham yang beredar.

a) Rasio Return on asset (ROA)

Pada perusahaan kertas dan pulp pada tiga tahun pengamatan dapat dilihat pada tabel berikut. 


\section{Tabel Rasio Return On Asset (ROA) Perusahaan Pulp And Paper Tahun 2017-2019}

\begin{tabular}{|c|l|c|c|c|}
\hline \multirow{2}{*}{ No } & \multicolumn{2}{|c|}{ Nama Perusahaan } & \multicolumn{3}{|c|}{ Tahun } \\
\cline { 3 - 5 } & & 2017 & 2018 & 2019 \\
\hline 1 & PT. Alkindo Naratama.Tbk & $5,82 \%$ & $5,47 \%$ & $6,08 \%$ \\
\hline 2 & PT. Toba Pulp Lestari. Tbk & $7,30 \%$ & $0,11 \%$ & $-4,05 \%$ \\
\hline 3 & PT. Tjiwi Kimia. Tbk. & $1,06 \%$ & $8,45 \%$ & $5,40 \%$ \\
\hline
\end{tabular}

Berdasarkan tabel di atas, terlihat perubahan-perubahan nilai return on asset (ROA) yang terjadi pada masingmasingperusahaam di setiap periodenya. Jika dilihat dari besaran ROA pertahunnya, terdapat beberapa dari perusahaan-perusahaan tersebut mengalami peningkatan nilai return on asset. Yang mengalami peningkatan yaitu PT Tjiwi Kimia.Tbk. Hal ini berarti bahwa semakin besar nilai return on asset menunjukkan kinerja perusahaan yang semakin baik karena tingkat pengembalian yang semakin besar. Hal ini terjadi pada PT. Tjiwi Kimia.Tbk. walaupun nilai return on asset perusahaan walaupun belum stabil. Sedangkan perusahaan yang mengalami penurunan nilai return on asset adalah PT. Toba Pulp Lestari.Tbk dan Perubahan kenaikan return on asset tertinggi dialami oleh PT. Alkindo Naratama.Tbk pada tahun 2019, pada tahun 2017 dan tahun 2018. Dimana dapat dikatakan bahwa perusahaan mengalami penurunan dengan nilai return on asset turun sebesar 0,35\%. Dan meningkat sebesar 0,61\% pada tahun 2019 .

\section{b) Rasio Return Of Equity (ROE)}

Return On Equity (ROE) merupakan salah satu rasio yang digunakan untuk mengukur Return on equity (ROE) adalah jumlah imbal hasil dari laba bersih terhadap ekuitas dan dinyatakan dalam bentuk persen. ROE digunakan untuk mengukur kemampuan suatu emiten dalam menghasilkan laba dengan bermodalkan ekuitas yang sudah diinvestasikan pemegang saham.Semakin tinggi ROE, semakin besar laba yang dihasilkan dari sejumlah dana yang diinvestasikan sehingga mencerminkan tingkat Kesehatan keuangan perusahaan.

Untuk lebih jelas, nilai return on equity (ROE) pada perusahaan kertas dan pulp pada tiga tahun pengamatan dapat dilihat pada tabel berikut.

Tabel Rasio Return on Equity (ROE) Perusahaan Pulp And Paper Tahun 2017-2019

\begin{tabular}{|c|l|c|c|c|}
\hline \multirow{2}{*}{ No } & \multirow{2}{*}{ Nama Perusahaan } & 2017 & 2018 & 2019 \\
\cline { 3 - 5 } & & & $10,75 \%$ & $10,55 \%$ \\
\hline 1 & PT. Alkindo Naratama.Tbk & $12.66 \%$ & & $-12,94 \%$ \\
\hline 2 & PT. Toba Pulp Lestari. Tbk & $15,13 \%$ & $0,27 \%$ & $12.01 \%$ \\
\hline 3 & PT. Tjiwi Kimia. Tbk. & $2,78 \%$ & $19,99 \%$ & \\
\hline
\end{tabular}


Berdasarkan tabel di atas, terlihat perubahan-perubahan nilai ROE yang terjadi pada masing-masing perusahaan di setiap periodenya. Jika dilihat dari besaran ROE pertahunnya, PTAlkindo Naratama.Tbk mengalami penurunan ROE pertahunnya. Hal ini mencerminkan bahwa terjadi penurunan laba pada tiap tahunnya dan hal ini berarti bahwa Kesehatan keuangan perusahaan tidak berjalan dengan baik. kemudian pada PT Toba Pulp Lestari.Tbk terjadi Penurunan Signifikan pada rasio ROE pada 2017 ke tahun 2018 yaitu sebesar14,86\% dan mengalami penurunan yang signifikan pada tahun 2019 yaitu sebesar-12,94\%. Hal ini juga menandakan terjadi penurunan laba dan terjadi krisis kesehatan pada perusahaan. Berbeda dengan PT. Tjiwi Kimia.Tbk dimana pada tahun 2018 mengalami peningkatan ROE secara signifikan. Akan tetapi hal ini menandakan bahwa terjadi kenaikan laba dan perusahaan mengalami tren yang positif pada tiap tahunnya.

Dari penjelasan di atas, maka dapat disimpulkan bahwa kinerja perusahaan PT Toba Pulp Lestari.Tbk menunjukkan kinerja yang kurang baik karena tingkat fluktuasi laba yang tidak menunjukkan tren positif.

c) Rasio Pertumbuhan

Rasio pertumbuhan (Growth ratio), merupakan rasio yang menggambarkan kemampuan perusahaan mempertahankan posisi ekonominya ditengah pertumbuhan perekonomian dan sektor usahannya. Rasio yang digunakan yaitu Earning Per Share (EPS). Adapun analisis rasio pertumbuhan perusahaan kertas dan Pulp adalah sebagai berikut.

\section{Tabel Rasio Earning Per Share (EPS) Perusahaan Pulp And Paper Tahun 2017-2019 \\ (Dalam Rupiah)}

\begin{tabular}{|c|l|c|c|c|}
\hline \multirow{2}{*}{ No } & \multirow{2}{*}{ Nama Perusahaan } & 2017 & 2018 & 2019 \\
\cline { 3 - 5 } & & & 28,72 & 29,35 \\
\hline 1 & PT. Alkindo Naratama.Tbk & 23,95 & & \\
\hline 2 & PT. Toba Pulp Lestari. Tbk & 240,36 & 4,86 & $-14,12$ \\
\hline 3 & PT. Tjiwi Kimia. Tbk. & 118,85 & $1,188.73$ & 53,48 \\
\hline
\end{tabular}

Dari tabel di atas, maka dapat dikemukakan bahwa terjadi tren kenaikan pada PT. Alkindo Naratama.Tbk pada tahun 2017 setelah terjadi peningkatan pertumbuhan sector usaha pada kurun waktu 2018 sampai 2019. Kemudian pada PT. Toba Pulp Lestari.Tbk terjadi penurunan EPS pada tahun 2017 hingga tahun 2019 EPS sebesar Rp.14,12,-. Hal ini menandakan bahwa
PT. Toba Pulp.Tbk mengalami penurunan laba yang signifikan pada tahun 2018 dan pada tahun 2019. Perusahaan yang mengalami tren positif adalah PT Tjiwi Kimia.Tbk dimana pada tahun 2017 hingga 2018 perusahaan mengalami pertumbuhan laba per lembar saham sebesar Rp.1,070.-. Hal ini menandakan bahwa terjadi pertumbuhan sektor usaha yang sangat sifgnifikan pada PT. Tjiwi 
Kimia.Tbk.

Dari hasil analisis data di atas, maka dapat dikemukakan bahwa perusahaan yang memilliki rasio profitabilitas yang baik atau dengan kata lain yaitu perusahaan yang memiliki kemampuan mencari keuntungan dan memiliki tingkat efektivitas manajemen suatu perusahaan adalah PT. Tjiwi Kimia.Tbk. Hal ini berdasarkan nilai ROA dan ROE yang mengalami peningkatan pada tiap tahun pengamatan. Sedangkan PT. Alkindo Naratama. Tbk memiliki rasio profititabilitas yang dikategorikan baik tetapi tidak signifikan tingkat penurunan rasio profitabitas perusahaan pada tiap tahun pengamatan. Kemudian pada PT Toba Pupl Lestari.Tbk dapat dikategorikan memiliki penurunan rasio profitabilitas dan rasio pertumbuhan pada tiap tahunnya.

\section{E. KESIMPULAN DAN SARAN}

1. Kesimpulan

Dari hasil analisa di atas, maka dapat ditarik simpulan sebagai berikut.

a) PT. Alkindo Naratama. Tbk memiliki rasio profititabilitas yaitu ROA dan ROE yang dikategorikan cukup baik walaupun mengalami penurunan rasio profitabitas perusahaan pada tiap tahun pengamatan.

Rasio pertumbuhan yaitu menggunakan rasio Earning Per Share mengalami peningkatan pertumbuhan.

b) PT Toba Pupl Lestari.Tbk dapat dikategorikan memiliki penurunan rasio profitabilitas pada tiap tahunnya, hal ini berdasarkan nilai ROA dan ROE perusahaan yang cenderung menurun drastis pada pada tahun 2017 sampai tahun 2019, Dan rasio pertumbuhan yaitu EPS juga mengalami penurunan dari tahun 2017 hingga tahun 2019 . Hal ini menandakan bahwa PT. Toba Pulp.Tbk mengalami penurunan labab ersih yang signifikan

c) PT. Tjiwi Kimia.Tbk pada tahun 2017-2019 memilliki rasio profitabilitas yaitu Rasio ROA ,perusahaan memiliki kemampuan mencari keuntungan dan memiliki tingkat efektivitas manajemen. Begitupun Rasio ROE yang mengalami peningkatan pada tiap tahun pengamatan.

Rasio pertumbuhan menggunakan rasio Earning Per Share mengalami tren positif dimana pada tahun 2017 dan tahun 2018 perusahaan mengalami pertumbuhan dan peningkatan meningkatkan laba bersih,hal ini perusahaan dikategorikan sangat baik kinerja keuangannya.

\section{Saran}

Dari hasil analisa di atas, maka dapat dikemukakan saran sebagai berikut :

a. Perusahaan yang mengalami penurunan rasio profitabilitas harus mampu meningkatkan efektivitas kinerja manajemen agar meningkatkan penjualan dan efisiensi dalam bebanperusahaan.

b. Perusahaan yang memiliki rasio profitabilitas yang baik, dapat lebih meningkatkan lagi kinerja keuangan agar dapat terus meningkatkan pencapaian keuntungan pada tiap tahunnya.

c. Perusahaan yang memiliki tren penurunan rasio pertumbuhan (Growth ratio), mengevaluasi kinerja keuangan perusahaan sehingga perusahaan dapat memperbaiki kendala perusahaan selama ini. 


\section{DAFTAR PUSTAKA}

Eduardus, Tandelilin, 2010. Portofolio dan Investasi Teori dan Aplikasi. Yogjakarta:Kanisius.

Naibaho,Franky 2011. Pengenalan Analisa Fundamental, (Jakarta: PT CIMB Securities Indonesia.

Hanafi, Mamduh dan Halim, Abdul, 2012. Analisis Laporan Keuangan.Edisi Ketiga. Cetakan Pertama. Penerbit UUP Sekolah Tinggi Ilmu Manajemen YKPN. Yogyakarta.

Hery, 2016. Finansial Ratio For Business (Analisis Keuangan Untuk Menilai Kondisi Finansial dan Kinerja Perusahaan).Jakarta: Penerbit PT. Grasindo.

Ikatan Akuntan Indonesia, 2013. Standar Akuntansi Keuangan Entintas Tanpa Akuntabilitas Publik. Dewan Standar Akuntansi Keuangan, Jakarta.

Fahmi, Irham. 2012. Pengantar Pasar Modal, Edisi Pertama, Bandung: Alfabeta.

Kasmir, 2010. Pengantar Manajemen Keuangan,Edisi Pertama, Jakarta: Kencana.

Kasmir, 2012. Laporan Keuangan, Jakarta: RajawaliPersada.

Kasmir, 2017.Analisis Laporan Keuangan, Jakarta: Rajawali Grafindo Persada.
Lukman Syamsuddin, 2011. Manajemen Keuangan Perusahaan, Jakarta: PT Raja Grafindo Persada.

Munawir, 2010. Analisis Laporan Keuangan. Edisi 4. Yogyakarta: Liberty

Ridwan Sundjaja, dkk, 2012.Manajemen Keuangan 2. Edisi 7. (Jakarta: Litera Lintas Media.

Sekaran, Uma. 2011. Research Methods for Bussines. Edisi 1 dan 2. Jakarta: Salemba Empat.

Sugiyono, 2013. Metodologi Penelitian Pendidikan. Bandung: Alfabeta.

Surtisno, 2012. Manajemen Keuangan Teori, Konsep dan Aplikasi. Yogyakarta: EKONISIA.

Sanusi, Anwar. 2012. Metodologi Penelitian Bisnis. Jakarta: SalembaEmpat.

Sedarmayanti dan Hidayat, Syarifudin, 2011. Metodologi Penelitian. Bandung: Mandar Maju.

Veitzal Rivai, dkk. 2012. Bank and Finansial Institution Management. (Jakarta: Raja Grafindo Persada.

www.kemenperin.go.id

www.jdih.bumn.go.id 